\title{
Ganoderma lucidum extract stimulates glucose uptake in L6 rat skeletal muscle cells
}

\author{
Kyung Hee Jung ${ }^{1}$, Eunyoung $\mathrm{Ha}^{2}$, Mi-Ja Kim ${ }^{3}$, Yoon Kyung Uhm ${ }^{1}$, Hye Kyung Kim ${ }^{4}$, \\ Seung-Jae Hong ${ }^{5}$, Joo-Ho Chung ${ }^{1}$ and Sung-Vin Yim ${ }^{1 凶}$ \\ ${ }^{1}$ Department of Pharmacology, ${ }^{2}$ Department of Biochemistry, College of Medicine, Kyung Hee University, \\ Seoul; ${ }^{3}$ Department of Obesity Science, Dongduk Women's University, Seoul; ${ }^{4}$ Department of Food and \\ Biotechnology, Hanseo University, Seosan; ${ }^{5}$ Division of Rheumatology, Department of Internal Medicine, \\ Kyung Hee Medical Center, Seoul, Republic of Korea; ${ }^{\varpi e-m a i l: ~ 94 p r i n c e s s @ h a n m a i l . n e t, ~ y s v i n @ k h u . a c . k r ~}$
}

Received: 29 March, 2006; revised: 18 August, 2006; accepted: 08 September, 2006 available on-line: 10 September, 2006

\begin{abstract}
The effect of Ganoderma lucidum extract on glucose uptake was studied in L6 rat skeletal muscle cells. G. lucidum extract increased glucose uptake about 2-fold compared to control. The extract stimulated the activity of phosphatidylinositol (PI) 3-kinase which is a major regulatory molecule in the glucose uptake pathway. About 7-fold increased activity of a PI 3-kinase was observed after treatment with G. lucidum extract, whereas PI 3-kinase inhibitor, LY294002, blocked the G. lucidum extract-stimulated PI 3-kinase activity in L6 skeletal muscle cells. Protein kinase B, a downstream mediator of PI 3-kinase, was also activated by G. lucidum extract. We then assessed the activity of AMP-activated protein kinase (AMPK), another regulatory molecule in the glucose uptake pathway. G. lucidum extract increased the phosphorylation level of both AMPK $\alpha 1$ and a2. Activity of p38 MAPK, a downstream mediator of AMPK, was also increased by G. lucidum extract. Taken together, these results suggest that G. lucidum extract may stimulate glucose uptake, through both PI 3-kinase and AMPK in L6 skeletal muscle cells thereby contributing to glucose homeostasis.
\end{abstract}

Keywords: Ganoderma lucidum extract, glucose uptake, phosphatidylinositol 3-kinase, AMP-activated protein kinase, skeletal muscle

\section{INTRODUCTION}

Ganoderma lucidum is an important medicinal fungus belonging to the Ganodermataceae family which has been popularly used for its health promoting properties (Stapleton et al., 1996; Vavvas et al., 1997; Thornton et al., 1998; Wasser \& Weis, 1999). It is consumed more for its pharmaceutical rather than nutritional value. The effects of G. lucidum extract on cancer, hypertension, hypercholesterolemia, and hepatitis have been demonstrated by several studies (Franz, 1989; Furusawa et al., 1992; Wang et al., 1997). In addition, it was reported that G. lucidum extract showed hypoglycemic activity by increasing plasma insulin and by affecting hepatic enzymes in alloxan-induced diabetic mice (Hikino et al., 1985).
Zhang \& Lin, (2004) reported that G. lucidum extract showed protective effect on alloxan-induced pancreatic islet damage.

Given that skeletal muscles account for more than $80 \%$ of insulin-stimulated glucose uptake, an impaired glucose uptake in skeletal muscle is responsible for the development of type II diabetes mellitus (Baron et al., 1991). Two major regulatory molecules of glucose uptake, phosphatidylinositol (PI) 3-kinase and AMP-activated protein kinase (AMPK), are responsible for glucose uptake into the cytoplasm (Musi et al., 2001; Xi et al., 2001). PI 3-kinase is stimulated by insulin and mediates glucose uptake (Xi et al., 2001). Activation of PI 3-kinase in impaired skeletal muscle showed a reduced effect on glucose uptake (Bjornholm et al., 1997; Dohm et

Abbreviations: AICAR, 5-aminoimidazole-4-carboxamide ribonucleoside; AMPK, AMP-activated protein kinase; DOG, 2deoxyglucose; PI 3-kinase, phosphatidylinositol 3-kinase; PKB, protein kinase B; LY, LY294002. 
al., 1998). Protein kinase B (PKB) is an enzyme that can be activated by insulin via a pathway involving a PI 3-kinase dependent mechanism and can promote glucose uptake (Chan et al., 1999). AMPK mediates contraction-induced glucose uptake AMPK $\alpha$, the catalytic subunits of AMPK, exists as two isofor$\mathrm{ms}, \alpha 1$ and $\alpha 2$. AMPK $\alpha 1$ is ubiquitously expressed in various tissues such as skeletal muscle, liver, and pancreas, while AMPK $\alpha 2$ is more limitedly expressed in skeletal and cardiac muscles (Cheung et al., 2000; Musi \& Goodyear, 2002).

Although a hypoglycemic effect of G. lucidum extract has been reported, the exact mechanism of this effect has yet to be elucidated. Therefore, we investigated the effect of G. lucidum extract on glucose uptake in skeletal muscle cells by assessing the activities of PI 3-kinase and AMPK, two crucial mediators in the glucose uptake pathway.

\section{MATERIALS AND METHODS}

Preparation of extract. G. lucidum was purchased at Kyungdong market (Seoul, Korea) and was authenticated by the College of Oriental Medicine, Semyung University. Methanol extract of G. lucidum (yield: $19.7 \%$ of dry weight) was obtained by $48 \mathrm{~h}$ maceration at room temperature and was filtered through a $0.45 \mu \mathrm{m}$ filter (Osmonics, Minnetonka, MN, USA), lyophilized, and kept at $4^{\circ} \mathrm{C}$.

Materials. All chemicals were purchased from Sigma-Aldrich Chemicals (St. Louis, MO, USA) unless otherwise indicated. Fetal bovine serum was purchased from Invitrogen (Carlsbad, CA, USA). Dulbecco's modified Eagle's medium (DMEM) and other culture products were purchased from GIBCO BRL (San Diego, CA, USA). [ $\gamma^{-32}$ P]ATP (6000 $\mathrm{Ci} / \mathrm{mmol})$ and $2-\left[{ }^{3} \mathrm{H}\right]$ deoxy-D-glucose $(6.0 \mathrm{Ci} / \mathrm{mmol})$ were purchased from PerkinElmer Life and Analytical Sciences, Inc. (Boston, MA, USA). The anti-phospho specific antibodies that recognize a phosphoactivated forms of AMPK $\alpha 1, \alpha 2$, p38 and PKB were from Upstate (Charlottesville, VA, USA) and Cell Signaling Technology (Beverly, MA, USA).

Cell culture. Monolayer of L6 skeletal muscle cells was maintained at subconfluent conditions in growth media containing DMEM with $0.045 \mathrm{~g} / \mathrm{ml}$ glucose, $100 \mathrm{U} / \mathrm{ml}$ penicillin, $100 \mu \mathrm{g} / \mathrm{ml}$ streptomycin, and $10 \%$ fetal bovine serum. Cells were maintained in a humidified $37^{\circ} \mathrm{C}$ incubator with ambient oxygen and $5 \% \mathrm{CO}_{2}$.

Glucose uptake assay. Glucose uptake was determined as previously described (Eichhorn et al., 2001). Cells were cultured on 12-well culture plates, washed with Krebs-Ringer phosphate buffer (KRB) (pH 7.4, $25 \mathrm{mM}$ Hepes, $118 \mathrm{mM} \mathrm{NaCl}, 4.8$ $\mathrm{mM} \mathrm{KCl}, 1.3 \mathrm{mM} \mathrm{CaCl}_{2}, 1.2 \mathrm{mM} \mathrm{KH} \mathrm{PO}_{4}, 1.3 \mathrm{mM}$
$\mathrm{MgSO}_{4}, 5 \mathrm{mM} \mathrm{NaHCO}$ ), $0.07 \%$ bovine serum albumin, and $5.5 \mathrm{mM}$ glucose and incubated in KRB for $60 \mathrm{~min}$. Cells were treated with $100 \mathrm{nM}$ insulin, or 20,50 , or $100 \mu \mathrm{g} / \mathrm{ml}$ of G. lucidum extract for 30 min. Glucose uptake was measured by adding 20 $\mu \mathrm{l}$ glucose mixture $(5 \mathrm{mM}$ 2-deoxyglucose and 0.5 $\mu \mathrm{Ci} 2-\left[{ }^{3} \mathrm{H}\right]$ deoxy-D-glucose in KRB) to $980 \mu \mathrm{KRB}$ followed by incubation for $20 \mathrm{~min}$ at $37^{\circ} \mathrm{C}$. Nonspecific glucose uptake was measured by parallel incubations in the presence of $10 \mu \mathrm{M}$ cytochalasin $B$, which blocks transporter-mediated glucose uptake, and was subtracted from the total uptake in each assay. Uptake was terminated by washing the cells three times with $1 \mathrm{ml}$ ice-cold phosphate-buffered saline (PBS). Cells were subsequently lysed with $0.5 \mathrm{ml}$ of $0.5 \mathrm{M} \mathrm{NaOH}$ solution containing $0.1 \%$ SDS, and the solution was rotated for $15 \mathrm{~min}$. Cell associated radioactivity was measured in a liquid scintillation counter (PerkinElmer Life and Analytical Sciences).

Immunoprecipitation. Immunoprecipitation was performed as previously described (Choi et al., 2006). After washing twice with ice-cold PBS, treated with $50 \mu \mathrm{g} / \mathrm{ml} \mathrm{G}$. lucidum extract were solubilized by incubation for $30 \mathrm{~min}$ in $1 \mathrm{ml}$ of lysis buffer $(\mathrm{pH}$ 7.5, $50 \mathrm{mM}$ Tris/ $\mathrm{HCl}, 150 \mathrm{mM} \mathrm{NaCl}, 1 \mathrm{mM} \mathrm{MgCl}{ }_{2}$, $1 \mathrm{mM} \mathrm{CaCl}, 1 \mathrm{mM}$ sodium orthovanadate, $100 \mathrm{mM}$ $\mathrm{NaF}, 1 \mathrm{mM}$ EGTA, 1\% Triton X-100, 10\% glycerol, leupeptin $(5 \mu \mathrm{g} / \mathrm{ml})$ and $1 \mathrm{mM}$ phenylmethylsulfonyl fluoride) on ice. The cell lysates were then centrifuged at $15000 \times \mathrm{g}$ for $15 \mathrm{~min}$ at $4^{\circ} \mathrm{C}$ and supernatant was harvested. For immunoprecipitation, 20 $\mu l$ of anti-phosphotyrosine antibody agarose beads was incubated with supernatant containing $500 \mu \mathrm{g}$ of protein for $1 \mathrm{~h}$ at $4^{\circ} \mathrm{C}$. Immunoprecipitates were washed three times with PBS containing 1\% Nonidet $\mathrm{P}-40$, three times with $100 \mathrm{mM}$ Tris/ $\mathrm{HCl}, \mathrm{pH} 7.5$, containing $500 \mathrm{mM} \mathrm{LiCl}$ and finally twice with 25 $\mathrm{mM}$ Tris/ $\mathrm{HCl}$ containing $100 \mathrm{mM} \mathrm{NaCl}$ and $1 \mathrm{mM}$ EDTA.

PI 3-kinase assay. Crude PI 3-kinase was obtained by immunoprecipitation with antiphosphotyrosine antibody (Kim et al., 2002). Cell lysates (500 $\mu \mathrm{g}$ protein) were incubated with $20 \mu \mathrm{l}$ of antiphosphotyrosine antibody agarose beads. After washing, the immunoprecipitates with PI 3-kinase activity were resuspended in $100 \mu \mathrm{l}$ of kinase assay buffer (20 mM Tris/ $\mathrm{HCl}, 75 \mathrm{mM} \mathrm{NaCl}, 10 \mathrm{mM} \mathrm{MgCl}_{2}, 200$ $\mu \mathrm{g} / \mathrm{ml}$ phosphatidylinositol, $1 \mathrm{mM}$ EGTA, $20 \mu \mathrm{M}$ ATP, $\left.10 \mu \mathrm{Ci}\left[\gamma^{3}{ }^{32} \mathrm{P}\right] \mathrm{ATP}\right)$ and incubated for $30 \mathrm{~min}$ at room temperature with constant shaking. PI 3kinase activity was measured by the phosphorylation of PI. The reaction was stopped by the addition of $100 \mu \mathrm{l} 1 \mathrm{M} \mathrm{HCl}$ and the reaction products were extracted with $200 \mu \mathrm{l}$ chloroform/methanol $(1: 1, v / v)$. The samples were centrifuged and the lower organic phase was harvested and applied to 
a silica gel thin-layer chromatography (TLC) plate (Merck, Aichach, Germany) coated with $1 \%$ potassium oxalate. TLC plates were developed in chloroform/methanol/ammonium hydroxide/water $(60: 47: 11.3: 2$, by vol.), dried, and visualized by autoradiography.

Immunoblotting. The cell lysates were centrifuged for $15 \mathrm{~min}$ at $12000 \times \mathrm{g}$ at $4^{\circ} \mathrm{C}$, and the supernatant was collected. Proteins were separated by SDS/PAGE and transferred onto nitrocellulose membrane (Schleicher \& Schuell, Middlesex, UK). After transfer, the membrane was blocked in $5 \%$ nonfat milk in Tris-buffered saline plus $0.1 \%$ Tween 20 (TBS-T) and then was incubated for 1 $\mathrm{h}$ at room temperature with 1:1000 diluted antibody against phospho-AMPK $\alpha 1, \alpha 2$, p38 MAPK or $\beta$-actin (Cell Signaling Technology, Beverly, MA, USA). Next, the membrane was washed in TBS-T followed by incubation with a horseradish peroxidase-conjugated secondary antibody (1:2000). The immunoreactive bands were visualized with an enhanced chemiluminescence kit (Amersham Pharmacia, Uppsala, Sweden).

Statistical analysis. Statistical analysis was performed using Student's $t$-test and one way analysis of variance (one way-ANOVA). The accepted level of significance was preset as $P$ value $<0.05$. Data are presented as means \pm S.E.M. All calculations were performed using SPSS software (SPSS, Inc., Chicago, IL, USA).

\section{RESULTS}

\section{G. lucidum extract stimulates glucose uptake in skeletal muscle cells}

We determined the effect of G. lucidum extract on glucose uptake using 2-[3H]deoxy-D-glucose in L6 skeletal muscle cells. Figure 1 shows that glucose uptake was increased by G. lucidum extract by about $85-90 \%$ compared to control $(P<0.01)$. The stimulatory effect of G. lucidum extract was dose-independent at dosages ranging from 20 to $100 \mu \mathrm{g} / \mathrm{ml}$. At the doses of 20, 50, and $100 \mu \mathrm{g} / \mathrm{ml}$ of the uptake G. lucidum extract was $183.4 \pm 8.1,195.3 \pm 6.8$, and $187.7 \pm$ $9.4 \%$, respectively, compared to control. The stimulatory effect of G. lucidum extract on glucose uptake was as strong as that of $100 \mathrm{nM}$ insulin (180.4 $\pm 8.6 \%$ ) (Fig. 1), which was used as a positive control (Maleppillil et al., 2005). These results indicate that G. lucidum extract stimulates glucose uptake in L6 skeletal muscle cells. Since the extract showed a dose-independent effect on glucose transport, the following experiments were set at $50 \mu \mathrm{g} / \mathrm{ml} \mathrm{G}$. lucidum extract.

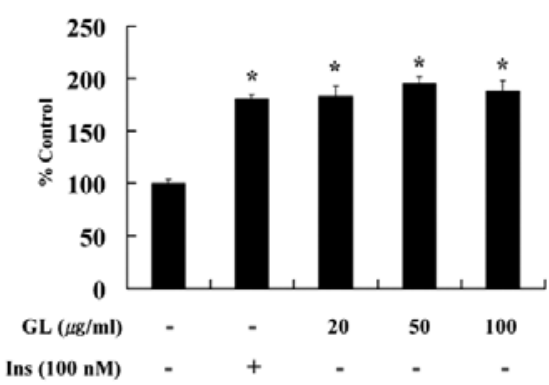

Figure 1. G. lucidum extract stimulates the rate of 2$\left[{ }^{3} \mathrm{H}\right]$ deoxy-D-glucose uptake in L6 skeletal muscle cells. Cells were treated with various doses of G. lucidum extract $(20-100 \mu \mathrm{g} / \mathrm{ml})$ for $30 \mathrm{~min}$ and $2-\left[{ }^{3} \mathrm{H}\right]$ deoxy-D-glucose uptake was measured in a scintillation counter. Insulin (100 $\mathrm{nM}$ ) was used as a positive control. Data represent the mean \pm standard error of five separate experiments, each performed in triplicate and presented as \% control. Ins, insulin; GL, G. lucidum extract, ${ }^{*} P<0.05$ vs. control.

\section{G. lucidum extract-stimulated glucose uptake is me- diated by PI 3-Kinase}

PI 3-kinase plays a critical role in insulin-stimulated glucose uptake. We performed PI 3-kinase assay using $\left[\gamma^{32} \mathrm{P}\right] \mathrm{ATP}$. In Fig. 2A, autoradiogram of a TLC plate shows the incorporation of ${ }^{32} \mathrm{P}$ into the $3^{\prime}$ position of PI. PI-3-phosphate (PI-3-P), which is formed by PI 3-kinase activity, was markedly increased by $100 \mathrm{nM}$ insulin for $30 \mathrm{~min}$ (about 6-fold compared to control). Insulin was used as a positive control (Ceddia et al., 2005). The levels of PI-3-P were increased by G. lucidum extract at 10,30 and 60 min compared to that of control. Densitometry analysis revealed that G. lucidum extract-stimulated PI 3-kinase activities at 10, 30, and $60 \mathrm{~min}$ were 5.8, 6.7, and 7.3-fold higher compared to those of the control, respectively. The G. lucidum extract-stimulated PI 3-kinase activity was attenuated by more than $90 \%$ by LY294002. The increase of PI 3-kinase activity by G. lucidum extract was significantly greater than that by $100 \mathrm{nM}$ insulin $(P<0.05)$. As shown in Fig. 2B, the phosphorylation level of PKB, a downstream effecter of PI 3-kinase, was increased by treatment with G. lucidum extract in a time-dependent manner. Treatment with LY294002 almost completely inhibited the G. lucidum extractstimulated phosphorylation level of PKB.

\section{G. lucidum extract-stimulated glucose uptake is me- diated by AMPK, and p38 MAPK}

To determine if the G. lucidum extract-stimulated glucose uptake was mediated by AMPK, we examined the phosphorylation levels of AMPK $\alpha 1, \alpha 2$ (catalytic subunits of AMPK) at Thr172 and p38 mitogen activated protein-kinase (p38 MAPK) proteins. 5-Aminoimidazole-4-carboxamide ribonucleoside (AICAR), a compound that activates AMPK, was then used as a positive control $(500 \mu \mathrm{M})($ Salt et al., 2000). 
$\mathbf{A}$

PI-3-P

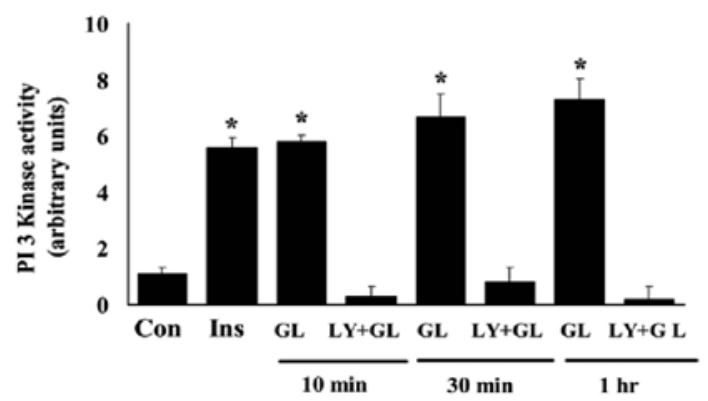

B

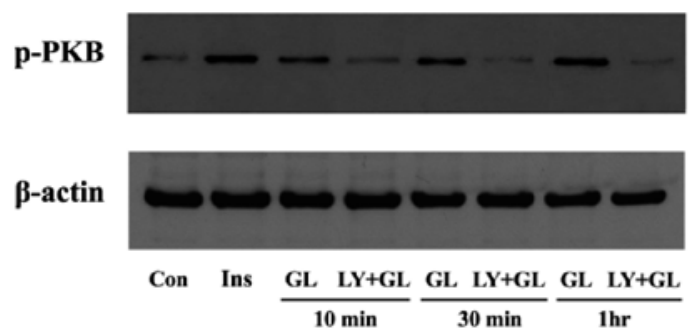

Figure 2. Effect of G. lucidum extract on phosphatidylinositol 3-kinase (PI 3-kinase) activity and phosphorylaton of protein kinase $B(\mathrm{PKB})$.

PI 3-kinase activity was measured in anti-phosphotyrosine immunocomplex. Cells were treated with $50 \mu \mathrm{g} / \mathrm{ml}$ G. lucidum extract and insulin $(100 \mathrm{nM}$, for $30 \mathrm{~min})$ was used as a positive control (A). The phosphorylation of PKB was analyzed by immunoblotting with antibodies specific to phosphorylation of PKB. Cells were treated with $50 \mu \mathrm{g} / \mathrm{ml} \mathrm{G}$. lucidum extract in the absence or presence of $20 \mu \mathrm{M}$ LY294002 (PI 3-kinase inhibitor) and 100 $\mathrm{nM}$ insulin for the indicated time. Beta actin was used as an internal control (B). Con, control; Ins, insulin; GL, G. lucidum extract; PI-3-P, phosphatidylinositol-3-phosphate; LY, LY294002; p-PKB, phospho-protein kinase B. ${ }^{*} \mathrm{P}<$ 0.05 vs. control.

A

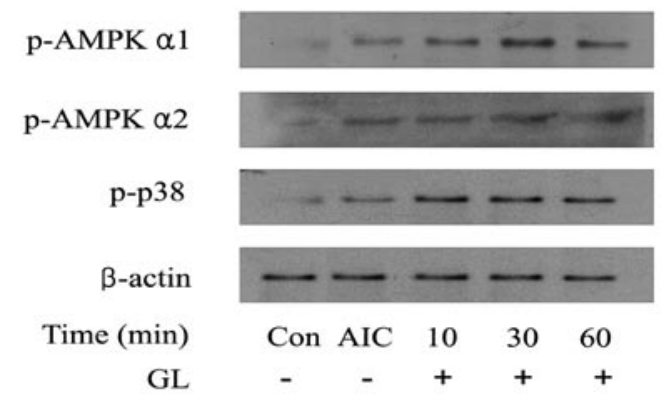

As shown in Fig. 3A, the phosphorylation level of AMPK $\alpha 1$ was clearly increased by G. lucidum extract at 10, 30 and $60 \mathrm{~min}$. The increased phosphorylation of AMPK $\alpha 1$ by G. lucidum extract was even greater than that by AICAR. Not as strong as for AMPK $\alpha 1$, a time-dependent increase in the phosphorylation level of AMPK $\alpha 2$ was also observed at 10, 30 and 60 min. p38 MAPK phosphorylation was accordingly increased at 10, 30 and $60 \mathrm{~min}$ (Fig. 3A). In an additional experiment, to determine whether AMPK and PI 3-kinase are component of the same signaling route, we investigated the phosphorylation level expression of PKB after treatment with AICAR in L6 skeletal muscle cells. The phosphorylation level of PKB was increased by insulin but not by AICAR (Fig. 3B). This result suggests that AMPK and PI 3-kinase may be component of different signaling route in L6 skeletal muscle cells. The intensity of $\beta$-actin, which was used as an internal control, was content.

\section{DISCUSSION}

G. lucidum extract has been used for long time in China to prevent and treat various human diseases such as hepatitis, hypertension, and hyperglycemic, turmorigenic and immunological diseases (Kabir et al., 1988; Kim et al., 1999; Cao et al., 2005; Kimura, 2005). Although a hypoglycemic effect of $G$. lucidum extract has been reported, its mechanism is not fully understood.

In skeletal muscle, glucose transport can be activated by at least two regulatory molecules, PI 3-kinase which is stimulated by insulin, and AMPK which is induced through muscle contraction (Zierath et al., 2000). PI 3-kinase activity has been suggested to be required for insulin-induced glucose uptake in skeletal muscle (Cheatham et al., 1994) and $\mathrm{PKB}$, a downstream mediator beyond PI 3-kinase,

B

Figure 3. Effects of G. lucidum extract on the phosphorylation of AMP-activated protein kinase (AMPK) $\alpha 1, \alpha 2$ at Thr-172, p38 mitogen activated protein kinase (p-38 MAPK) and protein kinase B (PKB).

Cell lysates were analyzed by immunoblotting with antibodies specific to phospho-AMPK $\alpha 1, \alpha 2$ at Thr-172, phosphop38 MAPK and phospho-PKB. Cells were treated with $50 \mu \mathrm{g} / \mathrm{ml} \mathrm{G}$. lucidum extract or $500 \mu \mathrm{M}$ AICAR for the indicated time. $\beta$-actin was used as an internal control. GL, G. lucidum extract; AIC, 5-aminoimidazole-4-carboxamide ribonucleoside; p-AMPK $\alpha 1, \alpha 2$, phospho-AMP-activated protein kinase $\alpha 1, \alpha 2$; p-p38, phospho-p38 mitogen activated protein kinase; $\mathrm{p}-\mathrm{PKB}$, phospho-protein kinase B. 
has been also implicated in insulin-stimulated glucose uptake (Brazil et al., 2004). To identify the signaling regulatory molecules involved in G. lucidum extract-stimulated glucose uptake, we investigated PI 3-kinase and PKB activities. As shown in Fig. 2A, G. lucidum extract stimulated PI 3-kinase with increasing time (10, 30, and $60 \mathrm{~min})$ and this-stimulated PI 3-kinase activity was decreased to basal line by LY294002. Moreover, PKB, a downstream mediator of PI 3-kinase, was also increased by G. lucidum extract. These data showing that PI 3-kinase is activated by G. lucidum extract treatment suggest that PI 3-kinase is involved in G. lucidum extract-stimulated glucose uptake in L6 skeletal muscle cells.

AMPK is another regulatory protein in the glucose uptake pathway and energy metabolism (Cortright \& Dohm, 1997; Brozinick \& Birnbaum, 1998). Activation of AMPK leads to the activation of p38 MAPK, implicating p38 MAPK as a downstream effecter of AMPK ( $\mathrm{Xi}_{\mathrm{i}}$ et al., 2001) We found that treatment of skeletal muscle cells with G. lucidum extract increased the phosphorylation levels of AMPK $\alpha 1, \alpha 2$ at Thr-172, and of p38 MAPK (Fig. 3A). Ha et al. (2006) reported that topiramate stimulated the rate of glucose transport in L6 skeletal muscle cells. From these results, we suggest that G. lucidum extract also increases glucose uptake by stimulating AMPK activity in skeletal muscle cells.

Recently, several reports have suggested that AMPK and PI 3-kinase are elements of one signaling route and cross talk to each other (Ouchi et al., 2004; Zou et al., 2004; Longnus et al., 2005) Others, however, considered AMPK and PI 3-kinase to be on separate signaling pathways in skeletal muscle (Hayashi et al., 1998; Zierath et al., 2000; Mu et al., 2001). In our experiments, it was found that PI 3-kinase and AMPK might be on different routes in mediating glucose uptake in L6 skeletal muscle cells (Fig. 3B).

In conclusion, we found that G. lucidum extract significantly stimulated glucose uptake in L6 skeletal muscle cells. An interesting result was that the increase of glucose uptake by G. lucidum extract might be mediated by both PI 3-kinase and AMPK.

\section{REFERENCES}

Baron AD, Laakso M, Brechtel G, Edelman SV (1991) J Clin Invest 87: 1186-1194.

Brazil D, Yang ZZ, Hemmings B (2004) Trends Biochem Sci 29: 233-242.

Bjornholm M, Kawano Y, Lehtihet M, Zierath JR (1997) Diabetes 46: 524-527.

Brozinick J Jr, Birnbaum MJ (1998) J Biol Chem 273: 1467914682.

Cao Y, Cao H, Chan E, Tang W, Xu A, Yang H, Huang M, Lan J, Li X, Duan W, Xu C, Zhou S (2005) Immunol Invest 34: 171-198.

Ceddia RB, Somwar R, Maida A, Fang X, Bikopoulos G, Sweeney G (2005) Diabetologia 48: 132-139.
Chan TO, Rittenhouse SE, Tsichlis PN (1999) Annu Rev Biochem 68: 965-1014.

Cheatham B, Vlahos CJ, Cheatham L, Wang L, Blenis J, Kahn CR (1994) Mol Cell Biol 14: 4902-4911.

Cheung PC, Salt IP, Davies SP, Hardie DG, Carling D (2000) Biochem J 346: 659-669.

Choi YK, Kim TK, Kim CJ, Lee JS, Oh SY, Joo HS, Foster DN, Hong KC, You S, Kim H (2006) Exp Mol Med 38: 11-17.

Cortright RN, Dohm GL (1997) Can J Appl Physiol 22: 519530.

Dohm GL, Tapscott EB, Pories WJ, Dabbs DJ, Flickinger EG, Meelheim D, Fushiki T, Atkinson SM, Elton CW, Caro JF (1988) J Clin Invest 82: 486-494.

Eichhorn J, Kayali AG, Austin DA, Webster NJ (2001) Biochem Biophys Res Commun 282: 615-620.

Fernandez CS, Cox T, Witters LA, Kemp BE (1996) J Biol Chem 271: 611-614.

Franz G (1989) Planta Med 55: 493-497.

Furusawa E, Chou SC, Furusawa S, Hirazami A, Dang Y (1992) Phytother Res 6: 300-304.

Ha E, Yim SV, Jung KH, Yoon SH, Zheng LT, Kim MJ, Hong SJ, Choe BK, Baik HH, Chung JH, Kim JW (2006) Pharmacogenomics J (Epub ahead of print).

Hayashi T, Hirshman MF, Kurth EJ, Winder WW, Goodyear LJ (1998) Diabetes 47: 1369-1373.

Hikino H, Konno C, Mirin Y, Hayashi T (1985) Planta Med 4: 339-340.

Kabir Y, Kimura S, Tamura T (1988) J Nutr Sci Vitaminol 34: 433-438.

Kim DH, Shim SB, Kim NJ, Jang IS (1999) Biol Pharm Bull 22: $162-164$.

Kimura Y (2005) In Vivo 19: 37-60.

Longnus SL, Segalen C, Giudicelli J, Sajan MP, Farese RV, Van Obberghen E (2005) Diabetologia 48: 2451-2453.

Maleppillil VV, Sandeep S, Rishi RC (2005) Britis J Pharm 10: $1-8$

Musi N, Goodyear LJ (2002) Curr Drug Targets Immune Endocr Metabol Disord 2: 119-127.

Musi N, Hayashi T, Fujii N, Hirshman MF, Witters LA, Goodyear LJ (2001) Am J Physiol Endocrinol Metab 280: E677-E684.

Mu J, Brozinick JT Jr, Valladares O, Bucan M, Birnbaum MJ (2001) Mol Cell 7: 1085-1094.

Ouchi N, Kobayashi H, Kihara S, Kumada M, Sato K, Inoue T, Funahashi T, Walsh K (2004) J Biol Chem 2: 1304-1309.

Salt IP, Connell JM, Gould GW (2000) Diabetes 49: 16491656.

Stapleton D, Mitchelhill KI, Gao G, Widmer J, Mitchell BJ, Teh T, House CM, Thornton C, Snowden M A, Carling D (1998) J Biol Chem 273: 12443-12450.

Vavvas D, Apazidis A, Saha AK, Gamble J, Patel A, Kemp BE, Witters LA, Ruderman NB (1997) J Biol Chem 272: 13255-13261.

Wang SY, Hsu ML, Hsu HC, Tzeng CH, Lee SS, Shiao MS, Ho CK (1997) Int J Cancer 70: 699-705.

Wasser SP, Weis AL (1999) Crit Rev Immunol 19: 65-96.

Xi X, Han J, Zhang JZ (2001) J Biol Chem 276: 41029-41034.

Zhang HN, Lin ZB (2004) Acta Pharmacol Sin 25: 191-195.

Zierath JR, Krook A, Wallberg-Henriksson H (2000) Diabetologia 43: 821-835.

Zou MH, Kirkpatrick SS, Davis BJ, Nelson JS, Wiles WG 4th, Schlattner U, Neumann D, Brownlee M, Freeman MB, Goldman MH (2004) J Biol Chem 42: 43940- 43945. 